\title{
Father Figures and Faction Leaders
}

\author{
Identification Strategies and Monarchical Imagery among Ordinary
}

Citizens of the Northern and Southern Low Countries (c. 1780-1820)

\author{
JANE JUDGE AND JORIS ODDENS
}

\begin{abstract}
After his ascension to the throne in 1813 , William Frederick was quickly accepted as a father-monarch who united the various factions previously vying for power in the Dutch Republic. When in 1815 the Sovereign Principality of the Netherlands merged with the former Austrian Netherlands to form the United Kingdom, the new Southern subjects were far less inclined to accept William I as father of the nation. So goes the prevailing interpretation in the historiography, based as it is on politically and culturally elite sources. In this article, we investigate how ordinary folk imagined the new monarch. We examine the identification strategies and monarchical imagery they employed in writing pauper letters, comparing the restoration monarchy with the various regimes that came before it. Ultimately, we conclude that, despite the officially sanctioned imagery, in both North and South, perceptions of the new monarch represented a less distinct rupture with the past than has been thought.
\end{abstract}

Vaderfiguren en factieleiders. Identificatiestrategieën en monarchale beeldspraak onder gewone burgers van de noordelijke en zuidelijke Lage Landen (ca. 1780-1820)

$\mathrm{Na}$ zijn aantreden in 1813 werd Willem Frederik al snel gezien als een vadermonarch met het vermogen alle facties die voorheen in de Republiek hadden bestaan te verbinden. Toen in 1815 het Soeverein Vorstendom der Nederlanden met de voormalige Oostenrijkse Nederlanden werd samengevoegd tot het Verenigd Koninkrijk, waren de nieuwe zuidelijke onderdanen veel minder geneigd om Willem I te beschouwen als vader van de natie. Dit is het dominante beeld in de geschiedschrijving, dat gebaseerd is op representaties van politieke en culturele elites. In dit artikel gaan we na hoe gewone mensen tegen de nieuwe monarch aankeken. We onderzoeken de identificatiestrategieën en monarchale 
beeldspraak waarvan zij zich in armenbrieven bedienden en vergelijken daarbij de restauratiemonarchie met verschillende regimes die eraan voorafgingen. We concluderen dat, de officiële beeldvorming daargelaten, de percepties van de nieuwe Oranjevorst zowel in het noorden als het zuiden een minder scherpe breuk behelzen dan tot nu toe werd gedacht.

This special issue is rooted in the hypothesis that, at the turn of the eighteenth century, as political regimes changed in whirlwinds of revolutionary fervour and restoration politics, people living in the Low Countries nevertheless exhibited continuity in their identities. Around 1800 , as new national identities emerged, older identities remained, manifested through traditions of civic engagement rooted in the practices of the Ancien Régime. One such custom comprised of individuals writing petitions to local and supra-local governors. Writing letters to request assistance was an active process by which subjects and citizens engaged with those in power and attempted to use the power-relationships of their society to their advantage. ${ }^{1}$ The content of petitions often (implicitly) described how supplicants saw themselves and those who organised their society. Thus, petitions reveal how ordinary people identified themselves and their rulers and understood the relationship between them.

In this article, we investigate how subjects and citizens from the Ancien Régime to the restoration monarchy envisaged their identities in the Northern and Southern Low Countries through petitions written to national power-holders. At the start of the post-Napoleonic restoration, in 1813, William Frederick took up his role as Sovereign Prince of the Netherlands. Much of the recent historiography maintains that he immediately succeeded in embodying the unity of the Dutch nation, unlike previous members of the House of Orange who had had a much more partisan profile, and unlike Louis Bonaparte, the French-born King of Holland. ${ }^{2}$ Two years later, when the Kingdom of the Netherlands was formed, the traditional narrative goes, the

Direct Interactions between Deputies and

“Ordinary Citizens" in France, ca. 189o-ca. 1940', Temps. Tidsskrift for Historie 4:8 (2014) 20.

2 Matthijs Lok and Natalie Scholz, 'The Return of the Loving Father: Masculinity, Legitimacy and the French and Dutch Restoration Monarchies (18131815)', BMGN - Low Countries Historical Review 127:1 (2012) 19-44; Henk te Velde, 'De herdenkingen en betekenis van 1813', in: Ido de Haan, Paul den Hoed, and Idem (eds.), Een nieuwe staat. Het begin van het Koninkrijk der Nederlanden (Amsterdam 2013) 363-376; Wilfried Uitterhoeve, 'De kleuringen van Oranje. Bedenkingen tegen oranjevertoon rond het vertrek van de Fransen eind 1813', De Negentiende Eeuw 38:2 (2014) 113-128; Jeroen Koch, 'The King as Father, Orangism and the Uses of a Hero: King William I of the Netherlands and the Prince of Orange, 1815-1840', in: Frank Lorenz Müller and Heidi Mehrkens (eds.), Royal Heirs and the Uses of Soft Power in Nineteenth-Century Europe (London 2016) 263-280. 
newly appended Southern Netherlanders never fully accepted King William I as father of the nation the way his Northern subjects did. ${ }^{3}$

Yet, petitions written to the new monarch asking him for relief from poverty suggest that this is but part of the story. As one of the few written records left by 'average' folk, these petitions provide unique glimpses into their imaginations and we use them here to complement the assertions that perceptions of William I represented a break with those national powerholders who had come directly before him. After briefly introducing our source material and describing our methodology, we detail the strategies supplicants employed in their petitions and explain what these unveil about the identities of the petitioners as well as their conceptions of their powerholders. Ultimately, our analysis highlights that the tendency to see 18131815 as a moment of rupture in the way people identified with their rulers is primarily the outcome of research into political and cultural elites. Our study of pauper letters shows that there was, at least among ordinary citizens, also a good deal of continuity in both the Northern and Southern Low Countries at the turn of the eighteenth century.

\section{Sources and Method}

A simple definition of a petition is a written appeal to an authority made by one or more citizens. ${ }^{4}$ In this article we are concerned with a subtype of petitions that is often referred to as pauper letters. We take paupers to be petitioners who request money or a job in order to escape from (relative) poverty. ${ }^{5}$ Those traditionally belonging to the legal category of personae

See for example Sébastien Dubois, L'invention de la Belgique. Genèse d'un État-Nation (Brussels 2005) 145; Jeroen van Zanten, Schielijk, Winzucht, Zwaarhoofd en Bedaard. Politieke discussie en oppositievorming 1813-1840 (Amsterdam 2004) 43-44; Jeroen Koch, Willem I: 1772-1843 (Amsterdam 2013) 287. petitioning is vast and rapidly growing, but see for general introductions the special issue on 'Petitions in Social History' that appeared as a supplement to the International Review of Social History 46:9 (2001), especially Lex Heerma van Voss, 'Introduction' (1-10) and Andreas Würgler, 'Voices from among the "Silent Masses": Humble Petitions and Social Conflicts in Early Modern Central Europe' (11-34) and the contributions to Brodie Waddell (ed.), Addressing Authority: An Online Symposium on Petitions and Supplications in Early Modern Society, https:// manyheadedmonster.wordpress.com/2016/11/01/ addressing-authority/.

5 Some historians consider petitions and pauper letters different epistolary genres, whereby the latter does not fully follow the conventions of the petitionary tradition. See for instance Steven King, 'The English Pauper Letter, 1790-1830s', Groniek 47:3/4 (2014) [2016] 307. Such an approach creates a dichotomy between formal and informal letters for poor relief, whereas it is probably more apt to picture the letters on a scale from strictly formal to strictly informal, with many possible hybrid forms. 
miserabiles (the poor sensu stricto) are usually overrepresented as signatories of pauper letters, but our sample also includes letters presented by middle and in some cases upper class citizens who were, or were in danger of becoming impoverished to such an extent that they would no longer be able to live in accordance with their proper state. Of crucial importance here is not the exact social station of these letter writers, but the fact that they, at the moment of writing, had no part in the fabrication of the official imagery surrounding national power-holders.

Pauper letters have been studied mostly by social historians who were interested in the history of poverty and poor relief. ${ }^{6}$ In working with such sources to understand 'average' opinions, it is important to bear in mind that, as Maarten Van Ginderachter reminds us, 'we cannot interpret [pauper letters] automatically as direct, unfiltered statements'. ${ }^{7}$ Yet, authors who have used these sources extensively concur that, as Steven King puts it, while 'pauper letters are not unproblematic as a source, [...] it is also possible to overplay the difficulties of using them'. ${ }^{8}$ It is obvious that pauper letters were presented in pursuit of self-interest and that authors were governed by strategic considerations; the choices they made in employing one strategy or another is what interests us here. We should also be aware of the fact that pauper letters were sometimes written by more or less 'professional' writers who frequently used conventional phrases.

Petitioners who wrote their requests themselves likewise followed certain scripts orally transmitted within communities of the poor. The existence of such scripts means that we cannot just assume that pauper letters were highly individual calls for help - even if in some cases they were precisely that. Given that the contents of these scripts changed over time and did not necessarily correspond to the contemporaneous official imagery, the pauper letters provide us with valuable information on collective mentalities of subaltern members of society.

Most notably in eighteenth and nineteenthcentury England: Thomas Sokoll, 'Selbstverständliche Armut. Armenbriefe in England 1750-1834', in: Winfried Schulze (ed.), Ego-Dokumente. Annäherung an den Menschen in der Geschichte (Berlin 1996) 227-271; Idem, Essex Pauper Letters, 1731-1837 (Oxford 2001); Idem, 'Writing for Relief: Rhetoric in English Pauper Letters, 1800-1834', in: Andreas Gestrich, Steven King and Lutz Raphael (eds.), Being Poor in Modern Europe: Historical Perspectives 1800-1940 (Oxford 2006) 91-111; Steven King, 'Pauper Letters as a Source', Family \& Community History 10:2
(2007) 167-170; King, 'The English Pauper Letter'; Peter Jones and Steven King, 'From Petition to Pauper Letter: The Development of an Epistolary Form', in: Idem (eds.), Obligation, Entitlement and Dispute under the English Poor Laws (Cambridge 2016) 53-77.

7 Maarten Van Ginderachter, 'Public Transcripts of Royalism. Pauper Letters to the Belgian Royal Family (1880-1940)', in: Jeroen Deploige and Gita Deneckere (eds.), Mystifying the Monarch: Studies of Discourse, Power, and History (Amsterdam 2006) 226.

8 King, 'Pauper Letters as a Source', 167. 


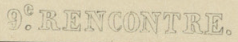

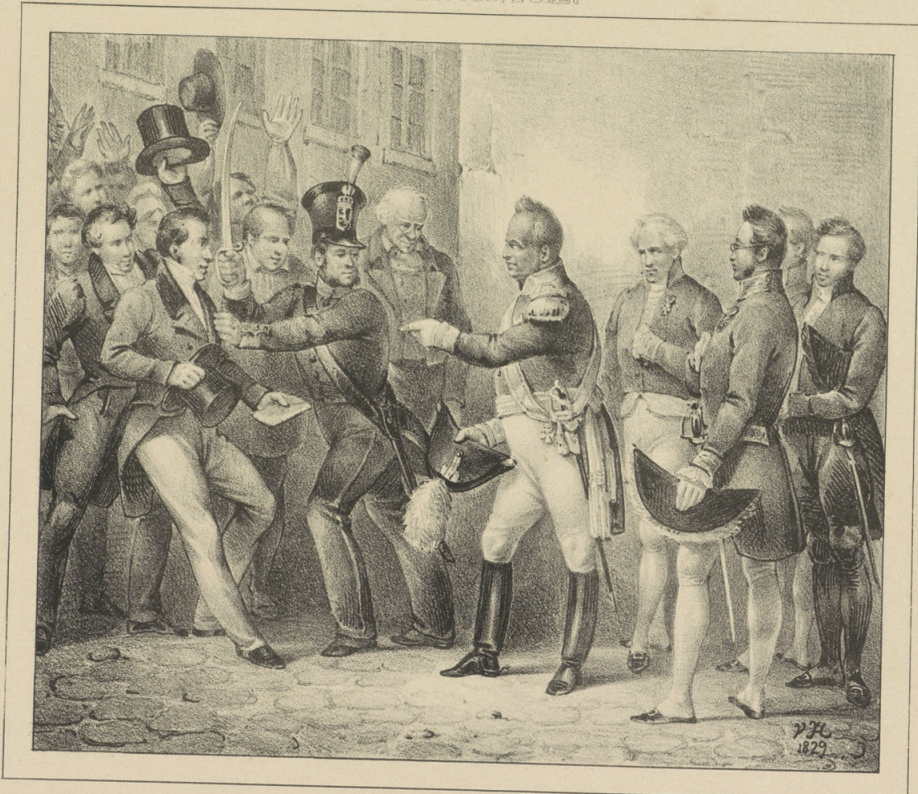

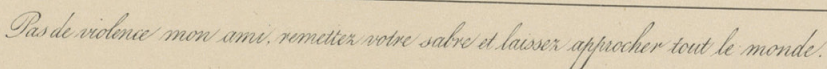

\section{$\Delta$}

Jean-Louis van Hemelryck, King William I allows a man with a petition to approach him, 1829. Print from the propagandistic series 'The Encounters', intended for his subjects in the southern provinces of the United Kingdom of the Netherlands, and showing King William I as a good father-monarch at a moment when this image was much more contested than at the start of his reign. Collection Rijksmuseum, Amsterdam, RP-P-OB-87.573. 
Usually studies of pauper letters operate in local contexts. Van Ginderachter, who deals with late nineteenth and early twentieth-century demandes de secours to members of the Belgian royal family, is one of the few historians to have studied pauper letters to authorities at the national level. ${ }^{9}$ When we consider them in the wider context of petitionary practices, such pauper letters can be seen as manifestations of the widespread phenomenon that subjects and citizens alike addressed their petitions directly to the highest authority in the state, in most cases the sovereign monarch, because they believed 'that a direct personal approach to a superior authority [...] was more effective than pursuing other bureaucratic channels' ${ }^{10}$ Some monarchs tolerated or even encouraged this practice because it added to their legitimacy, while others rejected it, claiming that they had better things to do and referring the petitioners to the official subaltern poor relief institutions. ${ }^{11}$

As well as being a transnational phenomenon, the practice of addressing pauper letters to national power-holders originated in premodern times and continued into the modern age. These factors make this source type particularly suitable for a comparative, diachronic study; however, the differences between the Northern and Southern Low Countries, and their many institutional ruptures around 1800 , have necessitated a pragmatic approach in selecting material. In some cases pauper letters are archived together, while in others they can be found in collections that contain various types of petitions. For some periods and regimes pauper letters are abundantly available, while for others they are rare and difficult to find. The numbers of pauper letters that are currently present in the archives cannot tell us much about the total numbers of citizens who sought help. Many of the extant letters contain references to other letters that were not found, indicating that the collections of written petitions that are held by the archives are incomplete, while the numerous oral requests that were brought to monarchs during personal audiences in most cases left no archival traces whatsoever. ${ }^{12}$

See also Idem, "'If your Majesty Would Only Send Me a Little Money to Help Buy an Elephant": Letters to the Belgian Royal Family (1880-1940)', in: Martin Lyons (ed.), Ordinary Writings, Personal Narratives: Writing Practices in 19th and Early 20thCentury Europe (Bern 2007) 69-83. Wrote to the Powerful', Journal of Social History 49:2 (2015) 326.

11 Cecilia Nubola, 'Supplications between Politics and Justice: The Northern and Southern Italian States in the Early Modern Age', International Review of Social History 46:9 (2001) supplement,
37; Hubertus Büschel, Untertanenliebe. Der Kult um deutsche Monarchen 1770-1830 (Göttingen 2006) 307-329; Derek Beales, 'Joseph II, Petitions and the Public Sphere', in: Hamish Scott and Brendan Simms (eds.), Cultures of Power in Europe during the Long Eighteenth Century (Cambridge 2007) 249-268; Thomas Shaw, 'Writing to the Prince: Supplications, Equity and Absolutism in Sixteenth-Century Tuscany', Past \& Present 215:1 (2012) 51-84; Hannah Weiss Muller, 'From Requête to Petition: Petitioning the Monarch Between Empires', The Historical Journal 60:3 (2016) 659-686.

12 Most rulers considered in this article held audiences with ordinary citizens as well as 


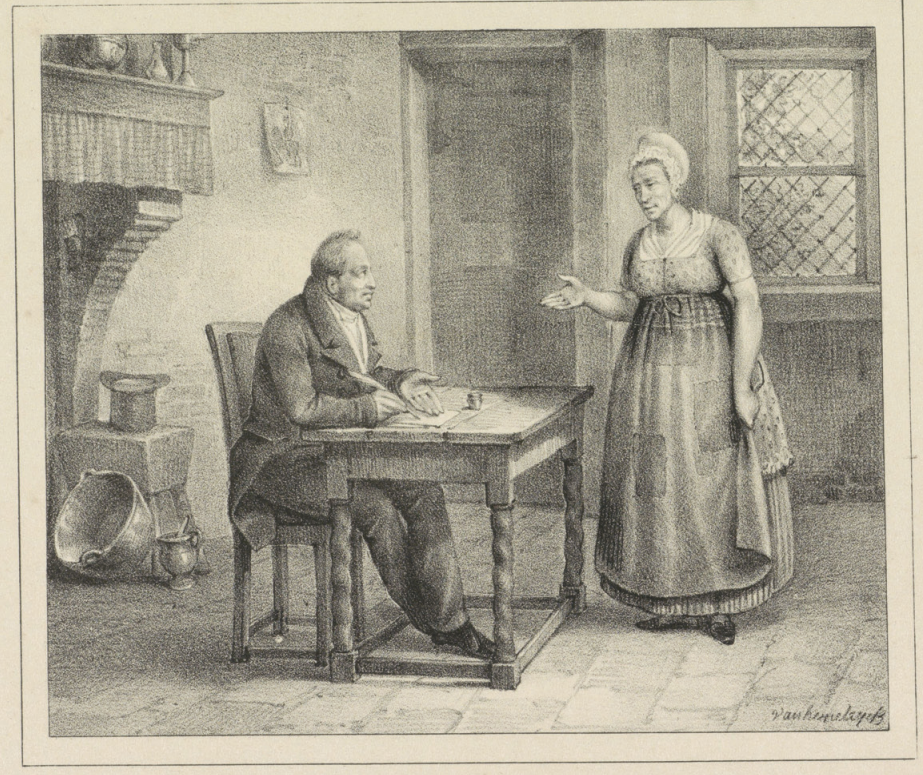

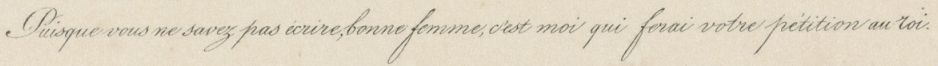

$\Delta$

Jean-Louis van Hemelryck, King William I helps an illiterate woman to write a petition addressed to himself, 1829. Print from the propagandistic series 'The Encounters'. Collection Rijksmuseum, Amsterdam, RP-P-OB-40.138. 
Given the different ways in which pauper letters were archived and the great differences in extant numbers, we worked our way through several hundreds of pauper letters. At times we read all of the letters that we could find, but more often we made selections from the abundantly available material. If the considerable difference in sample sizes complicates precise quantitative comparison between the various regimes, it remains perfectly possible to perform a qualitative assessment of the ruptures and continuities between the early reign of William $\mathrm{I}$ in North and South and the preceding period, which is the aim of this contribution.

Between 1780 and 1815 , both Netherlandish regions went through a number of political upheavals and regime changes. Our goal was to include pauper letters from North and South, written during various moments throughout this period and presented to different types of national powerholders. We made our actual selection of the source material with these criteria in mind and based on availability. For the Northern Netherlands before 1813 we considered a small number of pauper letters to Stadtholder William v, mostly from the post-Patriot restoration years, as well as larger samples of pauper letters presented to the parliamentary assemblies of the Batavian period and King Louis Bonaparte. ${ }^{13}$ For the Southern Netherlands,

receiving petitions. In some cases, a preference for oral requests on the part of the monarch may (partly) explain a scarcity or even lack of extant petitions. This seems to be the case for William $v$, and also for the interim revolutionary government in Brussels from 1830-1831, which we originally intended to include, but for which we only found records of oral supplications.

We consulted three boxes with miscellaneous petitions to William $v$ in the Royal Collections The Hague (RC), A31, Collection William v, inv. nos. 1003-1005 (1776-1794); twelve letters qualify as pauper letters. We identified three more pauper letters to William $\mathrm{v}$ among the papers of Willem Bentinck van Rhoon, one of William's most important courtiers during the restoration years, in the National Archives The Hague (NANL), 3.02.32, inv. nos. 14 and 16 (17871795). For the Batavian assemblies, we consulted pauper letters that form part of the collection of the parliamentary committee for former political exiles who had returned to the Netherlands after
1795: NANL, 2.01.01.01, Wetgevende Colleges, inv. no. 457. This committee served the subsequent parliamentary assemblies that convened in The Hague between 1796 and 1801. Many of the letters are indeed of impoverished former exiles, but letters sent to the parliamentary assemblies by 'ordinary' paupers also ended up in this collection. The letters are filed by last name of petitioner and in alphabetical order. We consulted the first box (letters A-B) out of a total of seven. This box holds 437 letters. For Louis Bonaparte we consulted a collection of miscellaneous petitions that include some ten pauper letters: NANL, 2.01.01.07, Staatssecretarie tijdens Lodewijk Napoleon, inv. nos. 330-331 (1806-1810); we also considered, in the same archive (inv. no. 662), a much larger collection of pauper letters in the collection of the Commission of Support (Commissie van Onderstand) that was instituted by the king in 1808. We consulted the first box out of a total of two, holding 378 letters from the year 1808 .

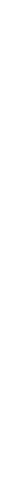


we examined a large sample of letters addressed to Joseph II, principally those presented to the Emperor when he visited the provinces in 1781, as well as an equally large sample of letters presented to Francis II in 1793 and 1794. We also examined the few surviving letters written to the Congress and Department of Veterans of the short-lived United States of Belgium in $1790 .{ }^{14}$ For the period after 1813 , we have selected, from the abundantly available material, samples of pauper letters presented to Sovereign Prince William Frederick before 1815 as well as samples of those given to King William I from both the northern and the southern half of the Kingdom of the Netherlands after $1815 .{ }^{15}$

In the next section, we present an overview of the different strategies petitioners employed in writing their requests during the pre-restoration period. In the third section, we present a similar outline for the years after 1813. As will become clear once we compare our findings for the pre- and post-1813 periods to each other and to the current historiographical consensus, the strategies supplicants used reveal much about the various ways in which ordinary citizens and subjects identified with national powerholders.

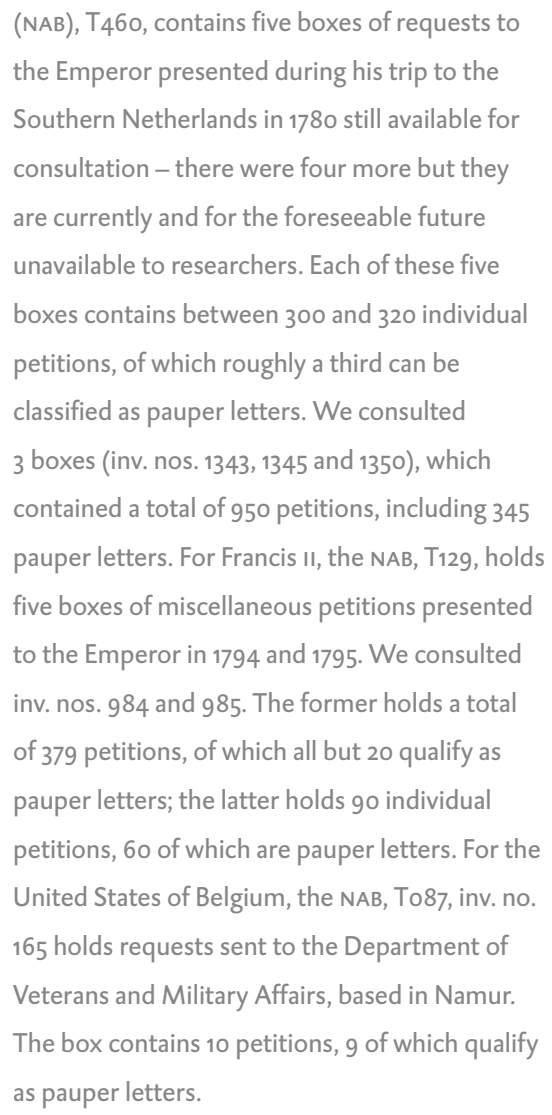

15 NANL, 2.02.01, Algemene Staatssecretarie, inv. no. 6108 (1813-1814) holds petitions to William Frederick about various topics; we considered thirty petitions that could be qualified as pauper letters. Large numbers of pauper letters to William I from the early years of the United Kingdom are held in the collection of the Royal Houses's Office of Philanthropy (Bureau van Weldadigheid). The actual office was founded in 1887; until then, requests for support were dealt with by the royal treasury and financial support was provided using the Royal Family's private funds: Charlotte Eymael, Inleiding op de inventaris van het archief van het Bureau van Weldadigheid, available at the Royal House Archives. We consulted RC, E15, Bureau van Weldadigheid, inv. nos. 30 (1816) and 32 (1817), 160 and 111 letters respectively. Finally, RC, Eo1d, Hofcommissie Brussel, holds a collection of pauper letters presented by subjects from the southern provinces to King William I and his wife, Queen Wilhelmina of Prussia, between 1819 and 1823. We consulted the first two boxes out of a total of four, i.e. inv. no. 1120 (1819, 80 letters) and inv. no. II21 (1820-1821, 62 letters). 


\section{Petitions Prior to William I}

From our sampling, it is clear that supplicants had several strategies at their disposal as they wrote petitions. Some petitioners used a variety of formulaic phrases in their wording while others were more personal. Some included great amounts of detail while others were content briefly to outline their problem and request. Overall, four major formulas surfaced in the surveyed petitions. Some were more universal than others but all four appear in only a portion of the given petitions, indicating that they were special tools in the petitions' chests, not the obligatory nuts and bolts of the petitions. The first two tropes, (1) poverty and (2) worthiness, were fairly straightforward. We argue they often merged into the more politicised and involved tropes of either identifying national power-holders with (3) a faction ${ }^{16}$ or (4) the fatherland. In all, these four themes are useful in evaluating how citizens and subjects formed their connection to their power-holders and how they displayed these in their pauper letters.

Many of those who petitioned sought to justify their case by emphasizing their (relative) poverty. In fact, this theme occurred in the vast majority of the letters throughout the decades before William I's reign. Of course, describing one's need is, to some extent, a necessary characteristic for a pauper letter. The strategic emphasis we discuss here goes beyond the simple fact of asking for financial aid and indicates, rather, the use of deliberate images in order to ameliorate one's chances at success. Letters that employed this strategy delineated details designed to go beyond the requisite show of need. While some writers described having to suffer true misery, 'without the least clothing or cover nor the ability to gather some', others wrote asking to be spared the indignity of having to live below their station. ${ }^{17}$ In general when employing this pauperism tactic, petitioners would declare their situation categorically dire in order to convince the power-holder that they deserved his or their help.

As with any strategy used in these letters, writers possessed choices regarding how to implement it, whether using a template, providing personal detail, adhering to the facts, or turning to more histrionic language. Most often, supplicants would simply claim that their situation was miserable, employing such formulaic phrases as 'I am living in such poverty' or 'the undersigned is so poor'. Some petitioners were more detailed and descriptive. carries negative connotations, we use the term here in its neutral sense. We mean to designate those with given political leanings who were part of loosely organised groups that had their roots in the pre-parliamentary political system, before the advent of political parties. The term usefully acknowledges that those included actively pursued their political interests at the expense of other groups but without ascribing the rigours of political parties.

17 NANL, 2.01.01.01, 457, Cornelis Blommers to the Representative Body, Utrecht, 1798. 
In 1790, a surgeon named De Cocq of St. Oedenrode wrote to William v, 'I have no bed in which to sleep'. ${ }^{18}$ Louis Bonaparte received many such petitions, as his Dutch subjects pleaded with him for help as they were "without any resource, $[. .$.$] missing everything, exposed to the last misery and the ruthless$ pursuit of our creditors', or 'fallen into the utmost poverty [with] no piece of bread for my starving children [and] no clothes with which to cover their nakedness' ${ }^{19}$ Letters to the assemblies of the revolutionary period, too, contained pitiable invocations of mothers who were 'almost without foodstuffs' for their children. ${ }^{20}$ Those in the Southern Low Countries also brought images of their need into play, as many of the petitions to Joseph II often present characteristically dramatic eighteenth-century rhetoric. An aging English ex-Jesuit, long a resident in the Austrian Netherlands, pleaded with Joseph II to grant him a pension since he had 'a lot of difficulty to live and work, not only because I am almost sixty, and only have one eye, but also because my other eye often fails me [...] and I have from time to time an ailment that brings me to despair'. ${ }^{21}$ Similarly, a petition on behalf of Jean Adam Hammé's widow described the woeful woman as, 'not even having a morsel of bread to drench with her tears'.22

Aside from plaintive portrayals verging on the maudlin, petitioners sometimes also attempted to curry their power-holder's favour and secure aid by demonstrating their worthiness. Where there were relatively similar illustrations of supplicants' impoverishment, when it came to worthiness writers had more choices to hand. Some were almost comical in the connections they made in making the case for their entitlement. Jean François de Kersmaker of Ghent wrote to Joseph II in 1781 asking for a job as court clerk in neighbouring Lokeren. As proof of his merit, he cited General Patico who 'had aged in the service of the august House of Austria and to which he was dedicated until his last breath', and the dowager who had founded the Patico Foundation in Brussels, 'animated by the same attachment and equally illustrious in her zeal for the good of the state (état) ${ }^{23}$ That dowager, de Kersmaker proudly explained, was the aunt of the baron whose wife was Kersmaker's own father's sister. Clearly, there could be no better choice for Lokeren's court clerk.

Other petitioners cited the personal skills that made them fit for a job, such as when Jean Baptiste Soulliard of Brussels told Francis II he would make an excellent guard during the Emperor's planned stay in the city. As a

Bonaparte, 1807; NANL, 2.01.01.07, 662, Geertruij Harmse to Louis Bonaparte, Amsterdam, 1808. Assembly, The Hague, 1796.
$21 \mathrm{NAB}, \mathrm{T} 460,1345$, Benjamin Blyde to Joseph II, Antwerp, 1781.

$22 \mathrm{NAB}, \mathrm{T} 460,1350$, Jean Adam Hammé's widow to Joseph II, Brussels, 1782.

$23 \mathrm{NAB}, \mathrm{T} 460,1345$, Jean François de Kersmaker to Joseph II, Ghent, 1781. 
professional hunter, 'he had served many Seigneurs of the Low-Countries, [notably] the Marquis du Chatelair during the war against the Turks, ${ }^{24}$ Similarly, in 1808, Frans Wortmans wrote to Louis Bonaparte asking for a job and specifically cited the seventeen years he had worked in Paris as proof of his merit, clearly under the impression that the years in the French capital would count for something. ${ }^{25}$ Using such examples allowed petitioners to position themselves as more worthy than others to claim the financial aid of the powerholder, whether charity or employment.

At times, strategies blended into each other or were deliberately used in tandem. The surgeon De Cocq, who had pleaded with William v that he had not even a bed, claimed that he had suffered poverty because of his commendable actions, which qualified him more than others for the Stadtholder's help. Indeed, De Cocq insisted that his poverty stemmed from his loyalty throughout the Patriot conflict of the 1780 os, during which he had lost his wealth. 'Oh great monarch,' he wrote referring to the years of conflict, 'I have defended your highness in all places and companies where you were slandered. What reward did we [his wife and him] receive for this other than strokes of the cane, beatings, insults, shame, hatred, anger, the total ruin of my practice. May your highness now think of me for once. ${ }^{26}$ In 1794 , during the short-lived Austrian restoration that saw Francis II monarch of the Southern Netherlands, a former professor at the University of Louvain, Joseph Le Plat, beseeched the Emperor 'to remember the justice and protection that he owes, particularly to the subjects oppressed for their devotion to the Sovereign' ${ }^{27} \mathrm{Le}$ Plat was worthy of salvation from poverty and insecurity because he had been loyal to the House of Austria during revolutionary upheaval, just as De Cocq had defended the House of Orange during the Patriot Revolt.

In expressing their worthiness to their national power-holders by virtue of their political loyalty, petitioners like De Cocq and Le Plat were employing the third and much more partisan strategy at the disposal of supplicants; namely, portraying the power-holder as leader of a given political faction. Clara Cornelia van Kervel used this strategy in writing to William v not long after his restoration in 1787 , stressing how much she had missed him during his absence from The Hague. She asked the Stadtholder to 'see in particular to those who have been suppressed because of [their loyalty to] your house'. ${ }^{28}$ Teunis Matters from Leiden recounted how much he had suffered during the Patriot era, when the Stadtholder's 'haters and enemies' had tried to force him to drink to William's downfall and imprisoned Matters when

26 RC, A31, 1004, J.C.A. de Cocq to William v, Sint Oedenrode, 1791. 


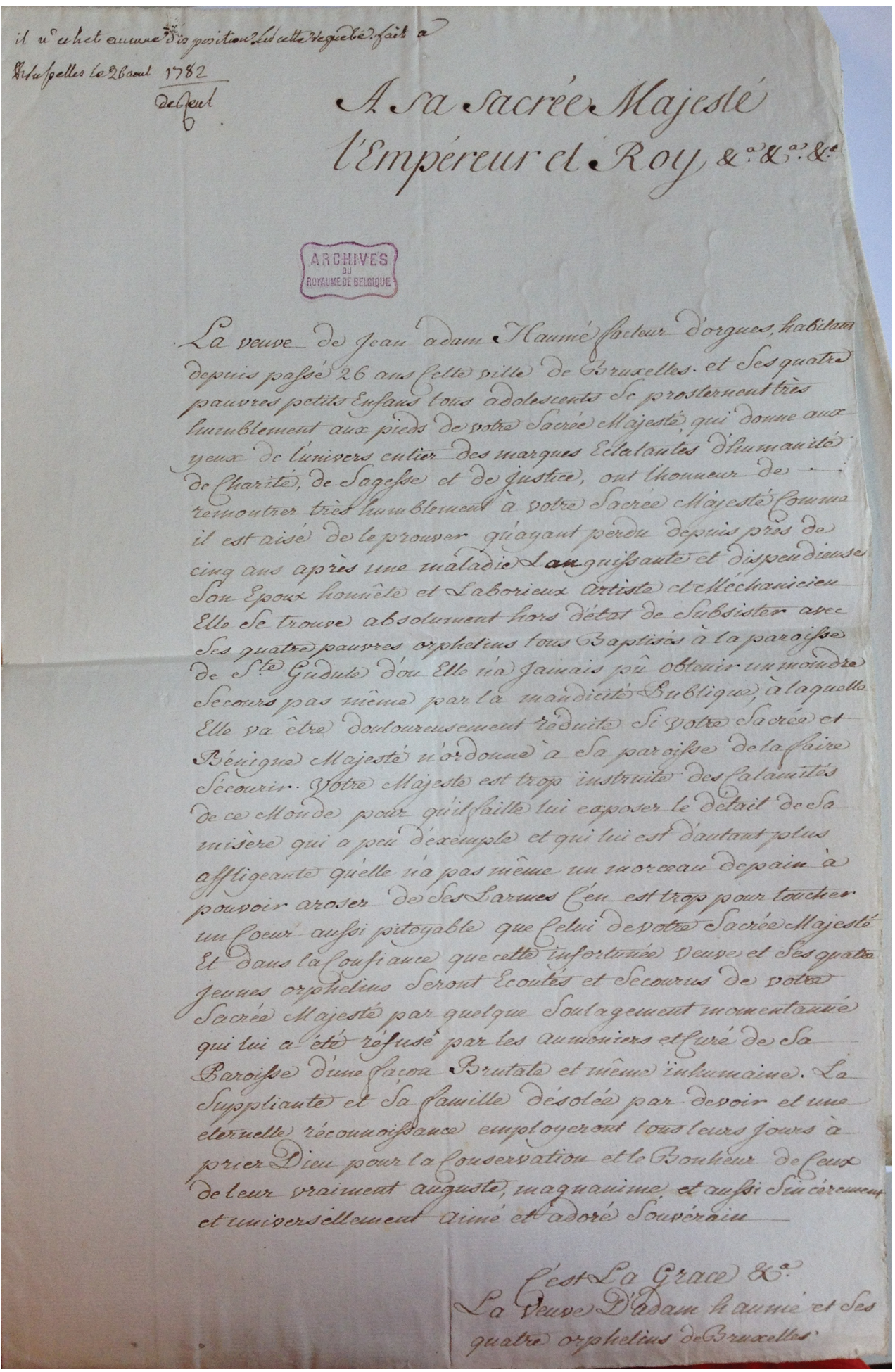

$\boldsymbol{\Delta}$

Letter by Jean Adam Hammé's widow to Joseph II, Brussels, 1782. This is an example of a letter written by a scribe. Collection National Archives of Belgium, Brussels, T46o, 1350. 
he refused. ${ }^{29}$ When petitioners reminded William $v$ of the sacrifices made and the sufferings undergone during the Patriot era, they appealed to his responsibilities as head of the Orangist faction, not as head of the entire Dutch Republic. Similarly, those who, like Le Plat, wrote to the Emperor Francis II after the shock of the revolution against Joseph II cast him as the champion of their royalist cause. The petitioners consciously chose to pursue a political identification with the power-holder, in which they crafted a relationship with him as head of their preferred faction.

Importantly, letters that appealed to power-holders as political leaders usually refrained from portraying them as benevolent rulers free from controversy. In the Austrian Netherlands, for instance, letters that emphasised partisanship largely disregarded Francis's role as unifying sovereign. Conversely, letters that cast Francis as the God-given sovereign did not mention the revolution at all, ignoring entirely any division or partisanship. In general, few attempts were made to reconcile factional and national leadership, though admittedly not every single petitioner felt that references to one or the other should be mutually exclusive. Jan Timmer's wife, while lamenting that her husband had lost his job as a labourer at the Amsterdam weighing-house 'because most of them are for the other side', addressed William $\mathrm{v}$ around 1790 as, 'my dear father and ruler of the state alongside God'. ${ }^{30}$

The use of the father metaphor to describe the ruler-subject relationship dates back to antiquity, but the meaning behind it expanded in the late middle ages when catechisms of all denominations took 'father' in the Biblical commandment 'honour thy father and thy mother' to refer equally to biological fathers and to spiritual and worldly leaders. ${ }^{31}$ In the second half of the eighteenth century, using the father metaphor cast the monarch in an entirely unpolitical light, as the merciful patriarch of all those under his rule. Due to the influence of the Enlightenment, the European-wide image of the father morphed into a loving and caring head of the family rather than a patriarchal authority figure. ${ }^{32}$ This explains the near universal use of this formula in petitions addressed to Joseph $\mathrm{II}^{33}$ Pierre le Filon's opening to his 1781 letter to the Emperor is characteristic as he asks, 'Where can I

Leiden, 1787.

Definition und Kritik des "Landesvaters" während

der frühen Neuzeit', Daphnis 11:1/2 (1982) 15-40;

Robert James Bast, Honor Your Fathers: Catechisms

and the Emergence of a Patriarchal Ideology in
Germany 1400-1600 (Leiden [etc.] 1997); Matthijs Wieldraaijer, Oranje op de kansel. De beeldvorming van Oranjestadhouders en hun vrouwen in preken, 1584-1795 (unpublished doctoral thesis, Vrije Universiteit Amsterdam 2014) 259. Lynn Hunt, The Family Romance of the French Revolution (Los Angeles 1992) ch. 2. 


\section{- Reqǘst}

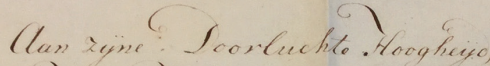

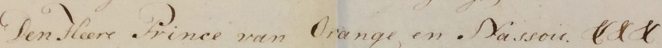

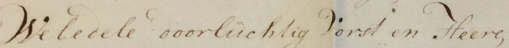

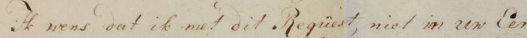

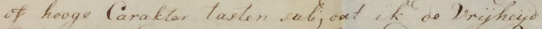

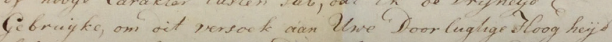

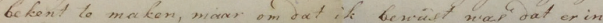

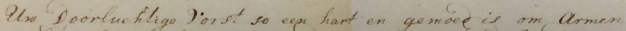

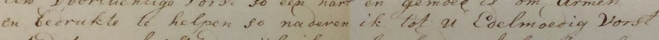

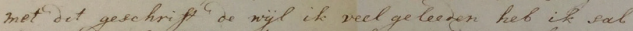

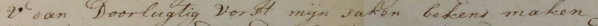

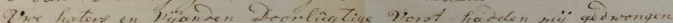

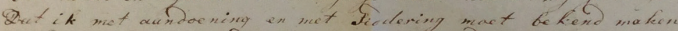

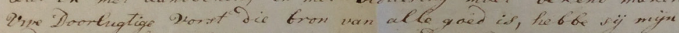

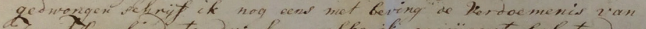

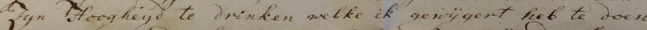

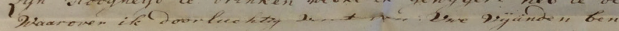

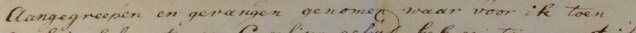

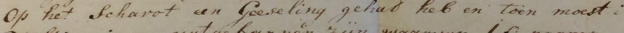

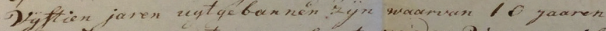

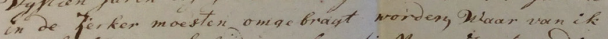

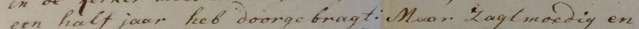

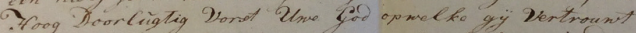

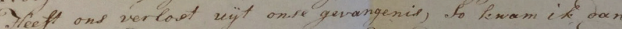

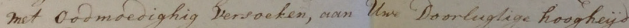

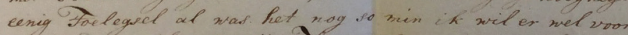

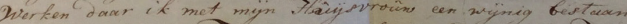

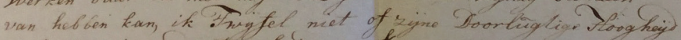

Sal mian in geragten howon: a

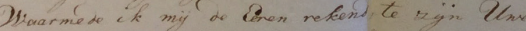

- Ir Pager Seve

il Cotory 110\%

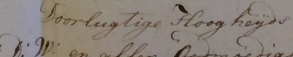

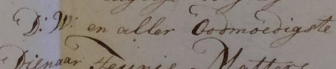

Q)ironagliag to fisce.

ind Bugels introver 
hope to find asylum if it is not at the feet of Your Majesty? Where will I lay my troubles if the Emperor my Father rebuffs me?’34 As an Ancien Régime emperor, Joseph represented his empire and his people in an abstract and holistic way, unmarred (at least at first) by accusations that he supported one political coterie over another. As seen in the pamphlet literature of the late 1780 , this familial harmony dwindled as Joseph's reforms solicited resistance and then open rebellion. Unfortunately, there are no extant pauper letters to the Emperor from the revolutionary period, rendering it impossible to know whether supplicants ceased to address him in fatherly terms. What is clear is that those petitions presented to his majesty at the beginning of his reign uniformly treated him as father to his people.

In the North, Louis Bonaparte also received many letters casting him in fatherly light. In 1808, Ms. J.P. Gueret, expressing a characteristic concern, did not know to whom else to turn other than to the king, her 'highest leader [...] who takes pity on a person in need like a father' ${ }^{35}$ Klaas Dekker, a soldier who had suffered an accident and could no longer earn a living for himself and his pregnant wife, took the king 'in his arms as a father' ${ }^{36}$ Moise Moresco, a Jewish citizen who was one of the rare petitioners to address the king in French instead of Dutch, referred to Louis Bonaparte as 'père de la patrie'. ${ }^{37}$ The conventional use of the image of the father-king in pauper letters indicates that subaltern levels of Dutch society were also receptive to the idea that Louis Bonaparte was effectively bound to his subjects like a father to the members of his family.

At certain times before 1813 , other family metaphors also appeared in pauper letters. Petitioners writing to republican regimes brought in by revolutionary experiments replaced fatherly rulers with brotherly leaders. This is logical given the proportional democratic thrust of the revolutionary experiments and the official rhetoric of fraternity, but the pauper letters commonly used fraternal language to supplement rather than substitute. In the South, the Department of Veterans for the Congress of the United States of Belgium in Brussels received letters from former patriot soldiers looking for work or financial support. These were tinged with fraternal triumph and oaths of 'inviolable attachment to [the] fatherland', and solicited the committee and congress on grounds that loyalty and partisanship merited due support. ${ }^{38}$ Even with these expressions of fellowship, petitioners' language largely remained deferential, an indication that the revolutionary regime retained some of the Ancien Régime's majesty. Petitioners opened with Antwerp, 1781. Bonaparte, Amsterdam, 1808.
37 NANL, 2.01.01.07, 331, Moise Moresco to Louis Bonaparte, Amsterdam, 1806.

38 NAB, To87, 165, J.M. Desavoije to the Comité des Vivres, 1790. 


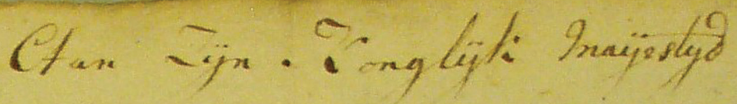

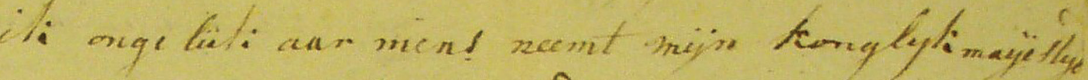

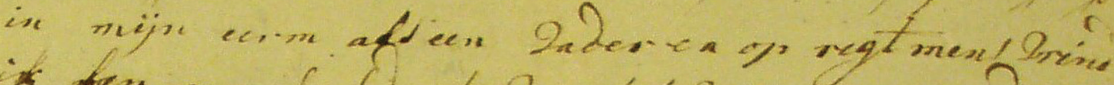

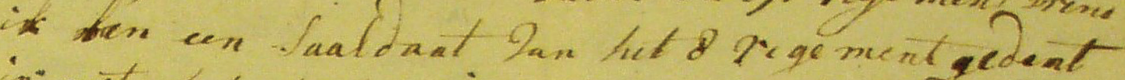

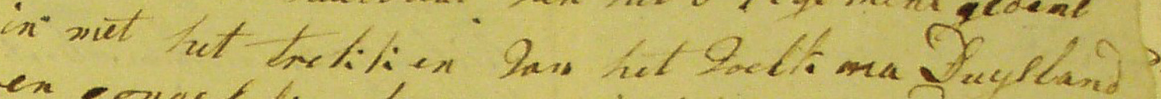

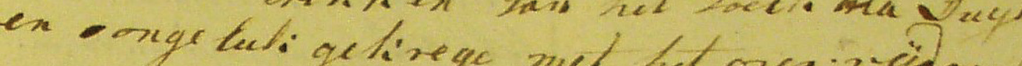

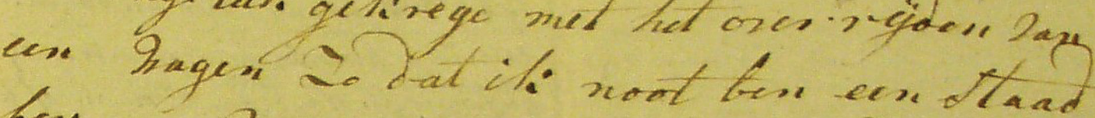
bere on 9 .

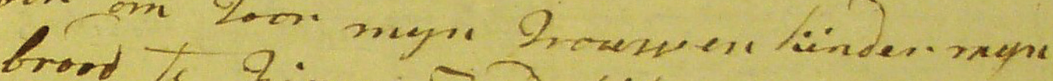
Zic

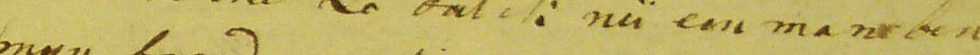

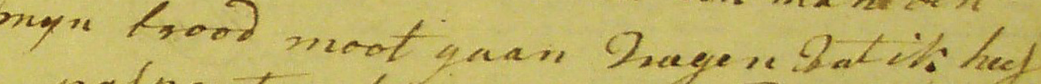

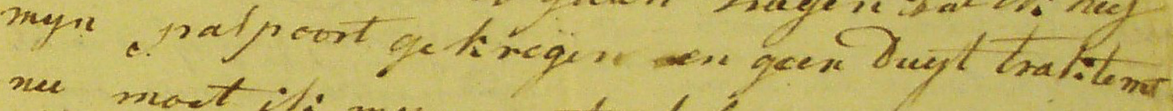

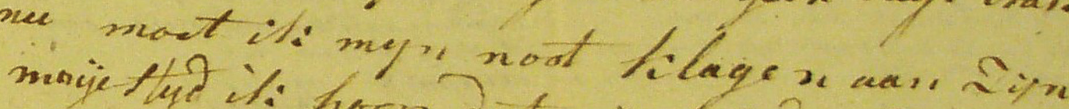

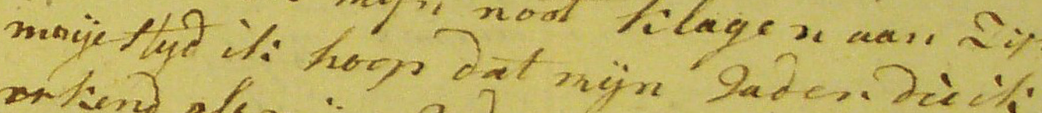

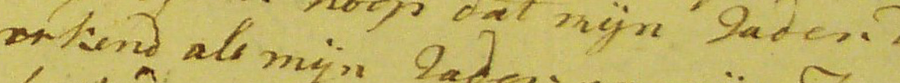

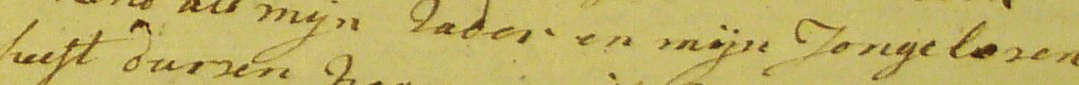

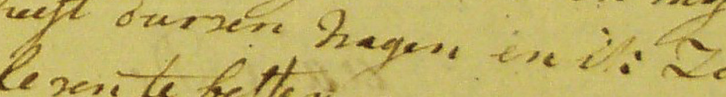

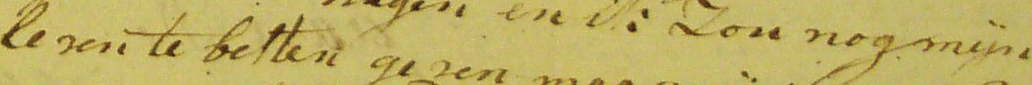

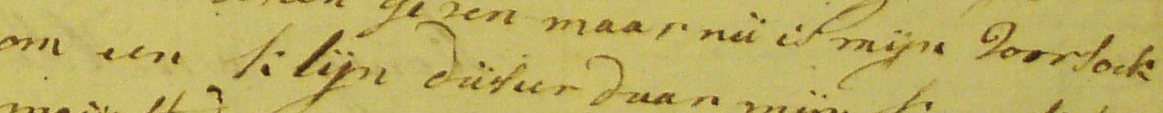

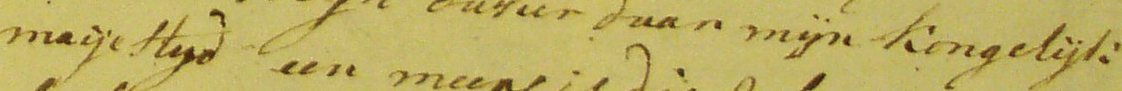

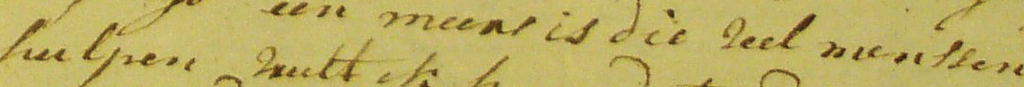

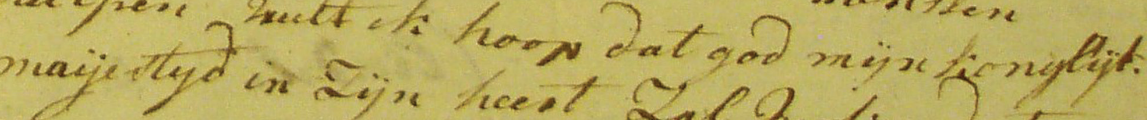

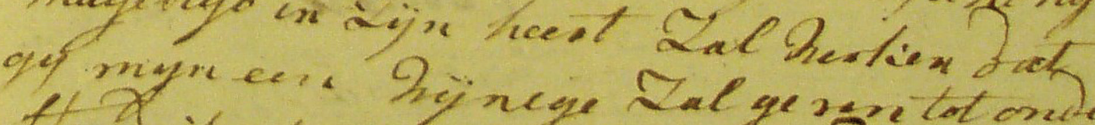

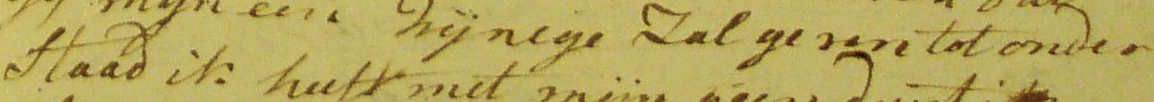

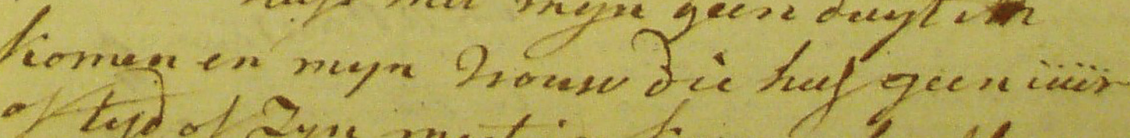
- typof ayre mod in tiven beratken plitgien Eientiendergoed

$$
\begin{aligned}
& \text { \%. Oon fleff mopic onderatasent } \\
& \text { I. Dan Detikes }
\end{aligned}
$$


phrases like 'Vos Hautes Puissances', addressing the 'very illustrious' delegates as 'Messeigneurs' whom they asked to 'deign' to listen to them as 'very humble supplicants'. ${ }^{39}$ Evidently, the fraternal and paternal intermingled.

In the Batavian Republic, letters mixed more egalitarian with less patriarchal language, though formulaic expressions of humbleness made up the backbone of most petitions. Batavian citizens requesting support opened their petitions with 'Fellow Citizens' or closed with 'Hail and Fraternity', and asked the revolutionary assembly to consider their miserable state 'with a brotherly and compassionate eye'. ${ }^{40}$ Yet, such strong fraternal phrases appear primarily in professionally written letters. The extant self-written petitions of the Batavian era suggest that professional rhetoric did not necessarily reflect a petitioner's personally preferred strategy. For instance, $\mathrm{M}$. Boner solicited the assembly 'for your fatherly support besides God [we] have no one to turn to but to you' and Everardus Bijleveld used a thorough mix of egalitarian language and paternalistic metaphors, referring to a 'solid faith in your fatherly love' and ending his letter with 'after having recommended myself to your fatherly care I remain with hail and fraternity honorable fathers your fellow citizen'.$^{41}$ Thus, where professional writers in the South fully embraced revolutionary rhetoric of brotherly compatriots, ordinary people in both North and South seem to have maintained a patriarchal image of those ruling them, even while their letters included fraternal expressions of harmony. Instead of a temporary rupture in the way ordinary citizens perceived their relationship with a ruler, amateur letters during the revolutionary eras indicate that supplicants continued to employ familial rhetoric, merely tailoring it in light of regime change.

Petitioners made similar tactical choices depending on context throughout the other decades before 1813. Some power-holders were more divisive than others, while some only acted so for given periods, causing supplicants to frame their more partisan letters in light of contemporaneous conditions. Thus, where adherence to the state was neutral as a show of worthiness to Joseph II (he represented the empire through his God-given sovereign status), it was largely an expression of factionalism to display one's loyalty to the House of Austria under Francis II. Similarly, before the Patriot Revolt, one finds petitions to William $\mathrm{v}$ that definitively situate him as a father figure, such as one from a widow in Rotterdam who 'turned now to the fatherly benevolence of your August Highness'.$^{42}$ After the Patriot era

Vivres, 1790; M. Pheissre to the Comite des

Vivres, 1790; François Joseph Hals to the Comité des Vivres, 1790.
41 NANL, 2.01.01.01, 457, Everardus Bijleveld to the National Assembly, The Hague, 1796.

42 RC, $A_{31}, 1003$, Johanna van Dijk to William v, Rotterdam, c. 1780. 
and William's restoration, petitioners took every opportunity to remind the Stadtholder that they had supported him and the House of Orange against the Patriot faction, which in their eyes apparently was the obvious argument to make, even if it detracted from the Stadtholder's desired reputation as an impartial ruler.

Our findings for the decades before $1813-1815$ are in line with the observation, made in recent literature on 'popular nationalism', that identification with the nation or with a national power-holder as the symbol of the nation is often at least partly 'motivational' in nature, which is to say that it is an attitude that is more or less consciously adopted to serve the personal interest of the person or people assuming such an identity. 43 Ordinary citizens of both the Northern and Southern Low Countries situated themselves as children in a harmonious family with the ruling fathermonarch at its head, but only at those moments when they judged this to be a potentially more successful strategy than reminding the monarch of a clientelist relationship, or appealing to poverty or worthiness. In the next section we consider whether petitioners started to make fundamentally divergent selections after 1813 .

\section{Petitions to William I}

In turning to letters written to William after 1813, we must first consider those letters sent to him from the Northern provinces, his traditional sphere of influence. The first impression of our sample emphasises the first two formulas we identified as being present in pauper letters. To be sure, a majority of the petitioners limited themselves to using the poverty and worthiness tropes and did not elaborate on what their new monarch represented to them. They applied the ubiquitous formulaic phrases (which also appear in pauper letters to sub-national levels of government or non-governmental poor relief institutions), appealing either to William's humanity in general or to his compassion to widows and orphans particularly. Though less prevalent, the letters also employed the two more complex tropes of identifying the monarch with either a faction or the fatherland.

We occasionally found metaphors that represented versions of the image of the father-monarch in the letters from the Northern provinces. Johannis Krijger from Middelburg 'threw [himself] like a child in front of your majesty's feet, convinced that you are a father for thousands of people

(Basingstoke 2012) 23-43; Anne Petterson, Eigenwijs vaderland. Populair nationalisme in negentiende-eeuws Amsterdam (Amsterdam 2017) 16 and passim. 
and a supporter of the common citizen'. ${ }^{44}$ Manus Vernhoud, a former soldier from Amsterdam, managed to produce an analogy that exactly captured the kind of message his monarch wished to convey:

\section{Just like I $[. .$.$] hope that his royal highness's return as a father over our$ motherland so deeply ruined by the French tyranny will lead to the restoration of the old glory and prosperity, I also hope and wish that it may please your royal highness to allow me to care for my family as a father. 45}

In contrast, whereas historians have often repeated that the factional antagonism of the revolutionary years ceased to be relevant by 1813 , this is not what we found in pauper letters from the period 1814-1817. Instead of acknowledging him as a good father above all parties, petitioners more commonly reminded William I of their loyalty to him and to his House and went into great detail about the trouble this loyalty had caused them. Some of these petitioners wrote of patronage relationships between members of their family and the House of Orange. Maria van Oosterveen's late husband had worked for the Orange family as a gardener for 36 years, and she had walked through the entire Kingdom trying to find the King in order to claim the pension she believed was due to her. ${ }^{46}$ Others wrote of love and sacrifices more ideological in nature. The husband of P. van Beemen had been fired from his job as sexton in the Frisian town of Harlingen because he had refused to renounce the House of Orange, and he had died shortly afterwards. ${ }^{47}$ Christina Meyse, whose late husband had served in the Imperial army under William I's brother 'when it was not possible to advance [the House of Orange] in the service of Holland', had endured sixteen weeks in prison and had her belongings plundered because of her attachment to the House of Orange, while the shock of all this had ruined her health and the tears she had shed spoiled her eyes. ${ }^{48} \mathrm{~A}$ scribe wrote a striking articulation of self-declared victimhood for the notorious Orangist publisher and pamphleteer Cornelis van der Aa's widow:

\footnotetext{
that the petitioner can support her request with no other rights than that she

$[\ldots]$ is the unhappy and needy widow of a man, who because of his honest opinions and loyalty to the beloved House of Orange, suffered for three years in a horrid prison! who even in the most dangerous days of tyranny and violence
} Middelburg, 1817 Frederick, Amsterdam, 1814.
47 NANL, 2.02.01, 6108, P. van Beemen to William Frederick, Amsterdam, 1814.

48 RC, E15, 30, Christina Meyse to William I, The Hague, 1816.

46 RC, E15, 30, Maria van Oosterveen to William I, The Hague, 1816. 
took honour in defending and commanding respect for the august and muchprayed-for House of Orange 49

In comparison, in the petitions sent to William I from the Southern Netherlands, only a small number contained language referencing the factional approach and these were from people who had previously lived in the Dutch Republic. ${ }^{50}$ For petitioners native to the Southern Netherlands, the factional profile of the House of Orange had little meaning.

Perhaps more surprising with respect to the supposed negative image of William I among his Southern subjects is the common occurrence of phrases that suggest filial identification with the new king. In many petitions, William I is routinely addressed as 'father of the people' and 'the best of all sovereigns'. More often than in the North, the use of such phrases is accompanied by an explicit adherence to the divine right of kings. Joseph Chassée, for example, an unemployed inhabitant of Brussels who called himself 'the most unfortunate of fathers', rejoiced that 'God has granted us a monarch, the best of fathers toward his people', and promised that his family would not stop praying for a long reign'. ${ }^{51}$ Adrien Grinberg, a thatcher with little work and a father of six, wrote 'I address myself to you, whom God has chosen to solace the unfortunate; you who replace God'. ${ }^{52}$ Furthermore, the author of the petition presented in name of Lucas Vercamme, an illiterate day laborer, recognized in William I a 'generous protector and father sensitive to the woes of his people', and gave assurances that Vercamme and his family would not stop lifting their arms toward heaven for the preservation of their King and his illustrious reign. ${ }^{53}$

One might think of such phrases as nothing more than formulaic expressions of submissiveness inherent to the petitioning culture of a Roman Catholic region whose inhabitants had long been used to monarchical rule: this is what William I's Southern subjects simply assumed kings wanted to hear, so this is what they wrote to their ruler when they asked him for a favour, regardless of their personal feelings. Yet, the very assumption that William I would want to be addressed in the same way as the sovereign rulers from the House of Habsburg is in itself a strong indicator of perceived continuity on the part of the petitioners: if they described the subject-monarch relationship in similar language as had been customary under the Ancien Régime, why would we assume that they saw William I in a particularly negative light?

\section{Amsterdam, 1816.}

RC, E01d, II21, M.F. Renot to William I, Brussels, 1821; RC, Eo1d, II21, Jacob Vizjevene to William I, Brussels, 1820-1821.
51 RC, Eo1d, II2O, Joseph Chassée to William I, Brussels, 1819 .

52 RC, Eo1d, II20, Adrien Grinberg to William I, Brussels, 1819 .

53 RC, Eo1d, II20, Lucas Vercamme to William I, Brussels, 1819 . 
Propitiously, the sources also offer more concrete clues as to how Southerners saw William. Quite a few of the petitions in the sample were written by (or in the name of) veterans of the Imperial army in which William I had served during the anti-Napoleonic campaign of 1809. They presented their faithful service to the 'emperor and king of Austria' as an argument for support, professing, like Léopold Deraime, a 68-year old former soldier who had been left handicapped by a saber thrust, to 'always have had zeal for the alliance'. ${ }^{54}$ Civilians equally seem to have perceived the reign of the House of Orange simply as an extension of that of the House of Habsburg, or even of French rule. Caroline Isabelle Josephe Devillers, an impoverished noblewoman, wrote to William I that her large family had no other income than a modest pain d'abbaye (pension), granted by Francis II in the 1790 o for services rendered to his illustrious House by her father, a baron..$^{55} \mathrm{~A}$ female petitioner of more humble origins, one of the few petitioners from the Southern provinces who wrote in a Dutch of sorts (her native tongue was clearly French), assured the King that she 'had so far never received anything from any monarch nor from any burgomaster' ['Ik hebt noeg noiet van giene Moenaerk iet gaet noeg van giene boergermiersste']. ${ }^{56}$ Such a statement strongly suggests that subsequent rulers did not appear to her in terms of who they were, but in terms of what they could do.

\section{Conclusion}

Recent studies frequently address the questions of how and when William Frederick, Prince of Orange-Nassau, and his House became symbols for the entire Dutch nation rather than just an Orangist faction. Though the precise timeline can vary, the fact that such a transition took place between 1813 and 1815 (although some interpretations include an incubation period during the Napoleonic years ${ }^{57}$ ) seems undebated. This literature typically situates the shift in perception that converted the Prince of Orange from a party leader to the father of the nation in elite circles, and correspondingly uses elitist sources - political speeches, pamphlets and poems, the occasional ego-document - to substantiate its claims. ${ }^{58}$

RC, E01d, II20, Léopold Deraime to William I, Brussels, 1819 .

RC, E01d, II21, Caroline Isabelle Josephe Devillers to William I, Brussels, 1821.

(Nijmegen 2013); and Bart Verheijen, Nederland onder Napoleon. Partijstrijd en natievorming 18011813 (Nijmegen 2017).
58 See footnote 2. On the predominance of the elitist perspective in the historiography on national identity in the restoration era, see Remieg Aerts, 'Hoe nationaal was het Verenigd Koninkrijk? Over het nationaal besef', in: Idem and Gita Deneckere (eds.) Het (on)verenigd koninkrijk, 1815-1830-2015. Een politiek experiment in de Lage Landen (n.p. 2015) 75. 


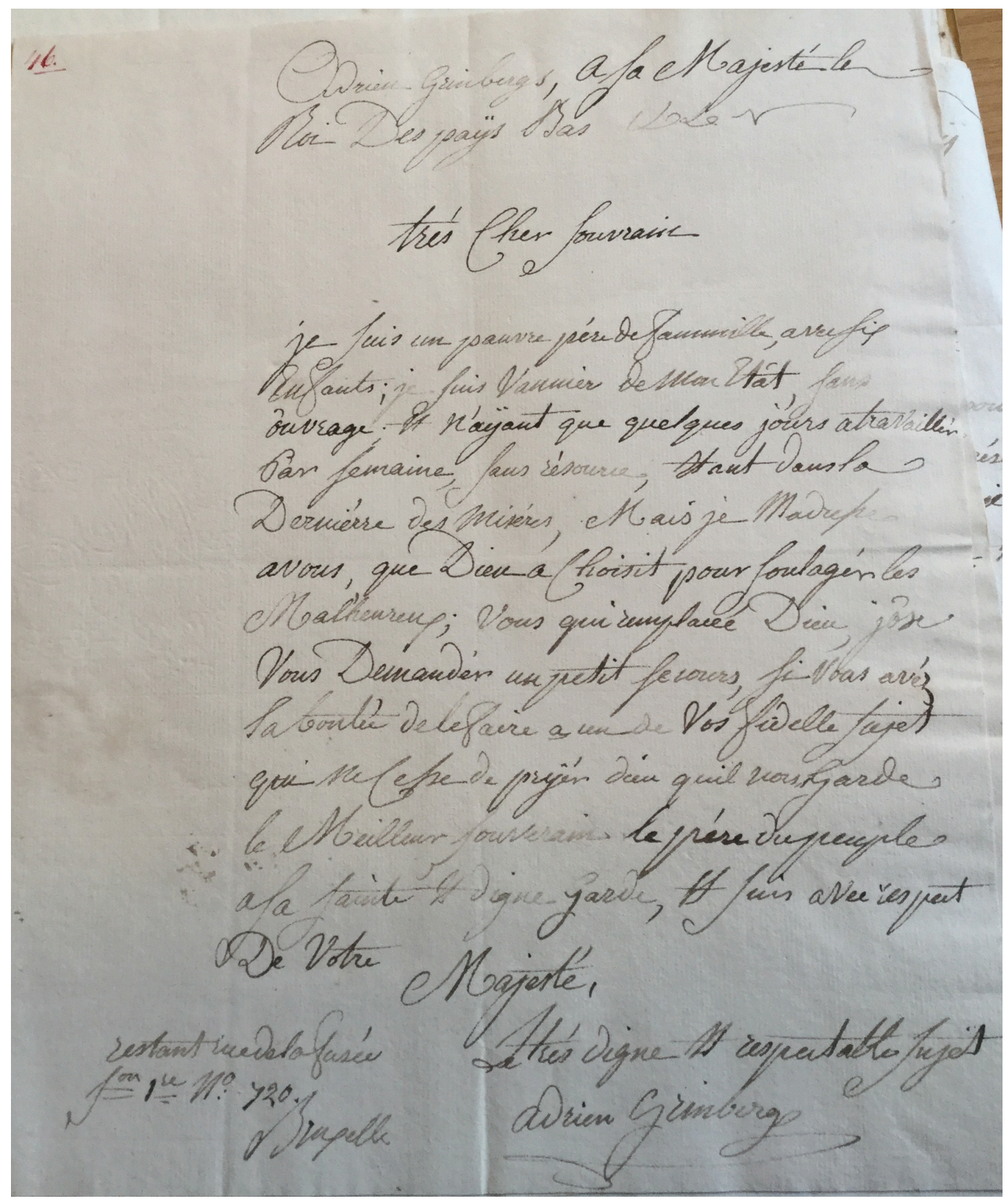

$\Delta$

Letter by Adrien Grinberg to William I, Brussels, 1819. Royal Collections, The Hague, Eo1d, II2O. 
Similar approaches are at the basis of the common assertion that when the Sovereign Principality of the Netherlands was merged with the former Austrian Netherlands to form the Kingdom of the Netherlands in 1815, subjects from the Southern provinces were less than enthusiastic about their new monarch and did not readily accept the image that they were the 'adopted children' of William I in his role as father-king. ${ }^{59}$ There are also studies which show that certain groups in the southern half of the United Kingdom did in fact welcome the new Orangist rule, but they too focus exclusively on political and cultural elites. ${ }^{60}$ As Els Witte points out, the extent to which Orangist sentiments were felt among the lower strata of society in the Southern Netherlands remains widely unknown. ${ }^{61}$

What happens, then, when we take both dominant views - the recognition of the new monarch as father of the nation by Northern Netherlanders and the Southern Netherlanders' reluctance to adhere to this image - and compare them to the language ordinary petitioners used? First and foremost, the letters to William I offer a thought-provoking alternative perspective. While the fact that some letters from the North addressed the new monarch as father indicates a broader non-elite permeation of this public image, Northerners who wrote to William using the faction strategy outnumbered those who employed fatherly language. The scripts they used do not at all match the official imagery surrounding William I, but are instead strongly reminiscent of those found in the letters to William $v$ after 1787 and Francis II in the 1790 . The crucial point is not that the image of the father-king occurs in Northern pauper letters, but rather that it occurs so sparingly. Compared, for example, to the sample of petitions to Louis Bonaparte, fatherly metaphors are decidedly less present in those to William Frederick/William I. This seems at the very least to nuance the position that the attempts to instill the image of Louis Bonaparte as father of the Dutch nation were ultimately unsuccessful, whereas attempts to do the same for William immediately fell on fertile ground. Similarly, the prevalence of faction in the letters from Northerners evinces a much stronger association of Ancien Régime Orangism with William's reign instead of the unifying image contemporary elites and subsequent historians portray. According to these

Zuidelijke Nederlanden. Betekenis en invloed ten tijde van de vorming van het Verenigd Koninkrijk, in: Piet Lenders (ed.), Het politiek personeel tijdens de overgang van het Ancien Regime naar het nieuwe regiem in België (1780-1830) (Kortrijk-Heule 1993) 85-97; Els Witte, 'De Oranjecultus in België. Tussen staats- en natievorming en contrarevolutie 1815-1850', in: Henk te Velde and Donald Haks (eds.), Oranje onder. Populair orangisme van Willem van Oranje tot nu (Amsterdam 2014) 157-176; Frank Judo, 'Een huisgemaakte hereniging. De “passiviteit" van de Zuid-Nederlandse elites in een context geplaatst', in: Stijn Van de Perre and Frank Judo (eds.), Belg en Bataaf. De wording van het Verenigd Koninkrijk der Nederlanden (Kalmthout 2016) 53-77.

61 Witte, 'De Oranjecultus in België', 164-165. 
pauper letters, ordinary Northern subjects of the Sovereign Principality and Kingdom of the Netherlands were more likely to see William as an extension of the House of Orange and less likely to see him as a benevolent father-king. The comparison with earlier time periods only serves to underline this.

The customary use of father metaphors in pauper letters to Louis Bonaparte offers a fresh outlook in the ongoing debate about how successful the King of Holland was in promoting his image as father of the Dutch nation. Some historians consider the nation building project under Louis Bonaparte 'a failure', and maintain that Louis Bonaparte, unlike William I, was not really accepted as paternal monarch by his Dutch subjects. ${ }^{62}$ Others argue that Louis Bonaparte was seen by many as 'father of the fatherland', but only after he had played a proactive role in the immediate aftermath of a number of disasters that happened during his reign. ${ }^{63}$ As with William I, such judgements are mostly based on sources produced by poets, painters, and politicians. These pauper letters indicate a more nuanced reality. Neither William I nor Louis Bonaparte fulfills the orthodox images of them. William was more factional in the North and Louis was more readily seen as a benevolent monarch by the Dutch than elite sources lead us to believe.

Similarly, the Southerners who wrote to William I asking for financial aid demonstrate that he was more often than not treated in the same way as the monarchs who had come before him. Petitions to William as 'the best of all fathers for his people' used language practically identical to those addressed to 'the Emperor, my father' Joseph II or that likened Francis II to their own father. ${ }^{64}$ While the reasons people may have used such language likely has much to do with long-ingrained culture, it remains clear that they considered William I to be a monarch due filial respect, and assumed that reminding him of his fatherly duties to his subject children would lead to a successful outcome for their requests. Thus, rather than being unable to see William as anything more than an Orangist foreign sovereign, the ordinary people who wrote these pauper letters were evidently able to accept him, at least on some level, as their paternal ruler. van Lodewijk Napoleon. Nederland als "objet de désir"', De Negentiende Eeuw 30:3/4 (2006) 145-146; Ido de Haan and Jeroen van Zanten, 'Lodewijk als wegbereider van Willem? Kritische kanttekeningen bij een nieuw idée reçue', De Negentiende Eeuw 30:3/4 (2006) 299-300.

63 Frans Grijzenhout, 'Lodewijk Napoleon. Beeld en zelfbeeld', in: Paul Rem and George Sanders (eds.), Lodewijk Napoleon. Aan het hof van onze eerste koning (Zutphen 2006) 13; Lotte Jensen,

“"See our Succumbing Fatherland, Overwhelmed by Disaster, Woe and Strife": Coping with Crisis during the Reign of Louis Bonaparte', Dutch Crossing 40:2 (2016) 151-164.

64 RC, Eo1d, II2O, Joseph Chassée to William I, Brussels, 1819.; NAB, T46o, 1345, Pierre le Filon to Joseph II, Antwerp, 1781; NAB, T129, 985, the Miller sisters to Francis II, 1794. 
Strikingly, despite predictable fluctuations in some of the language when it came to regime change, the rhetoric and strategies supplicants used in pauper letters remained largely the same from the Ancien Régime to the restoration period. Right down to the formulaic phrases, Low Countries petitioners soliciting economic assistance treated monarchs from William $\mathrm{v}$ and Joseph II to William I similarly. People chose strategies they thought would succeed, identifying themselves as particularly pitiable or especially worthy of succor. They also identified their monarch in a way that they thought would flatter and thus lead to a positive response, whether as the leader of the faction to which they were loyal or as the compassionate father who cared for his children in the tradition of God the Father. In French and Dutch, from villages and cities, from stadtholders to emperors and kings, citizens and subjects in the Northern and Southern Netherlands alike persisted in identifying their national power-holders in given ways. Their perceptions of the ties that bound them remained the same.

Jane Judge (1985) is currently working as an events coordinator at Leuven MindGate. Until the end of 2017 she was a postdoctoral research fellow at the KU Leuven history department. In 2015 she received her PhD in history from the University of Edinburgh; she wrote her doctoral thesis on the history of the United States of Belgium and its place in the wider age of revolutions. Recent publications: The United States of Belgium: The Story of the First Belgian Revolution (Leuven, autumn 2018); 'An Age in Microcosm: the United States of Belgium', in: Ben Marsh and Mike Rapport (eds.), Understanding and Teaching the Age of Revolutions (Madison 2017); 'The Scottish-American Enlightenment', in: Julia Straub (ed.), Handbook of Transatlantic North American Studies (Berlin/New York 2016) 545-561; 'Qu'allons-nous devenir? Belgian National Identity in the Age of Revolution', in: Lotte Jensen (ed.), The Roots of Nationalism. National Identity Formation in Early Modern Europe, 1600-1815 (Amsterdam 2016) 291-307. Email: jane.judge@kuleuven.be.

Joris Oddens (1981) is a postdoctoral researcher at the Leiden University Institute for History. He has published widely on the political and cultural history of the Dutch age of revolution. Over the past few years he has mostly been concerned with the theory and practice of petitioning in the Netherlands around 1800. Recent publications: 'De Nederlandse revolutie in dorp en stad. Lokale geschiedschrijving over de patriotsBataafse tijd, 1875 tot heden', Tijdschrift voor Geschiedenis 130:4 (2017) 565-591; 'The Greatest Right of Them All: The Debate on the Right to Petition in the Netherlands from the Dutch Republic to the Kingdom (c. 1750-1830)', European History Quarterly 47:4 (2017) 634-656; (with Ivo Nieuwenhuis), 'Using Satire in Historical Research: Comments on the Practice of Petitioning from the Dutch Age of Revolution (c. 1780-1800)', EighteenthCentury Studies 51:2 (2017) 219-233. Email: j.oddens@hum.leidenuniv.nl. 